\title{
Performance and Carcass Characteristics of
} Layer Chickens Fed Diets Containing Prosopis
Africana Seed Coat Meal Treated with Polyzyme® Odeh, M.O. ${ }^{1}$, Attah, S $^{2}$ and Abang, F.B.P2

${ }^{1}$ Department of Agricultural Education, School of Vocational \& Technical Education, College of Education, Oju, Benue State Nigeria. ${ }^{2}$ Department of Animal Production, College of Animal Science, University of Agriculture, Makurdi, Benue, State, Nigeria.

*Corresponding author: mosesodeh65@gmial.com

Abstract - The study evaluated the effect of prosopis Africana seed coat meal (PASCM) on the performance and carcass characteristics of three hundred (300) Nera brown layer chickens that were fed for a period of 39 weeks. The birds were randomly allotted to 5 experimental diets with 3 replications of 20 birds each. The diets were formulated with the inclusion of PASCM at 0,15,20,25 and 30\% levels for treatments $T_{1}, T_{2}, T_{3}, T_{4}$ and $T_{5}$, respectively and the data collected were subjected to analysis of Variance in a completely randomized design. Results obtained showed that all the productive parameters were affected $(P<0.05)$ by the dietary treatments except mortality that was not affected $(P>0.05)$. Carcass parameters, carcass cut and internal organs were not affected $(P>0.05)$ by the dietary treatments however, GIT parts were affected $(P<0.05)$ by the diets. Performance indicators and carcass characteristics showed that 20\% PASCM inclusion level resulted in optimum production and hence recommended for adoption.

Keywords-PASCM, Pullet Layer Chickens, Performance and Carcass Characteristics.

\section{INTRODUCTION}

Inadequate supplies of feedstuffs at economic prices continue to limit the production of animal protein in Nigeria. This is because the cost of animal feed accounts for $60 \%$ and $70 \%$ of the cost of production in poultry enterprises in Nigeria. Nutritionists and other professionals therefore, strive to reduce this cost to maximize profit (Aletor, 2005; Odeh et al., 2012).

This high cost of feed ingredients has scared some farmers from investing in poultry business (Musa and Olarinde, 2008). The conventional feed like maize continues to be expensive. Maize constitutes the main component of energy diet in poultry production in Nigeria, suggesting that any increase in the price of maize may increase the price of animal products. Therefore, there is the need to find an alternative feed resource which can replace maize (Eruvbetine et al., 2003, Kwari, 2008) in the diets of pullet layer chickens. The use of agricultural by-products and kitchen wastes like maize bran, rice bran and Prosopis africana seed coat meal (PASCM) etc. as feed resources can be achieved in poultry diet after careful study. This will help to reduce the competition for maize and increase animal protein at a relatively lower cost and improve net profit (Dafwang and Shwarmen, 1996; Oluyemi and Roberts, 2000; Diarra et al., 2002; Yusuf et al., 2008).

The availability of PASCM and its free acquisition brings it into focus as a replacement for maize in poultry nutrition. PASCM is high in crude fibre and low in energy compared to maize diet but can be used to replace maize as energy source (Sanni, 2015; Abang et al., 2016) in layer chickens diets with some exogenous enzymes (e.g polyzme $\left.{ }^{\circledR}\right)$ fortification (Chesson, 1993; Bedford and Morgan, 1996; Classen 1996). This study was sought to provide alternative feedstuffs to address the global feed crisis with the use of PASCM without affecting the performance and carcass characteristics in layer chicken nutrition.

\section{MATERIALS AND METHODS}

\section{Experimental Site}

This study was conducted at the poultry unit of Ohagwu farm, Ochodu Ukpa Igede, Oju Local Government Area of Benue State, Nigeria. Oju Local Government Area lies between latitude $6^{0} 51^{1}$ north and Longitude $8^{0} 25^{1}$ east in the Southern Guinea Zone of Nigeria, with a climate that has two 
distinct seasons. The wet season covers mid-March to midNovember, while dry season starts in late November to early March in which high temperature is experienced between February and April. Oju Local Government Area has an annual rainfall ranging from $1200 \mathrm{~mm}$ to $1500 \mathrm{~mm}$. The temperatures are generally very high during the day, particularly in March and April with a mean daily temperature of $26^{\circ} \mathrm{C}$, and daily minimum temperature of $16^{\circ} \mathrm{C}$ to $21^{\circ} \mathrm{C}$ and maximum daily temperature of $31^{\circ} \mathrm{C}$ to $37^{\circ} \mathrm{C}$ in dry and wet seasons. The relative humidity ranges from $42 \%$ to $75 \%$ depending on the time of the day and season of the year (Oju physical Setting Online Nigeria.Com, 2003).

\section{Test ingredient}

Prosopis africana seed coat meal (PASCM) was sourced from women in Oju Local Government Area that produced food condiment (Okpehe or Dawadawa) from prosopis africana seeds.

\section{Experimental Birds and Management}

A total of 300 Nera brown pullet layer chickens were randomly divided into five groups in a complete randomized design with each treatment having three replicates containing twenty birds per replicate. The experimental study which lasted for 39 weeks had five diets that were formulated from a mixture of maize, Prosopis africana seed coat meal, soybean meal, rice bran, blood meal, bone meal, palm oil and vitamin/mineral/premix as shown in Table 1. They were intensively managed in deep litter system throughout the experimental period. Feed and water were servedad libitum.

\section{Dietary treatment}

The PASCM was sundried for 10 days and milled. It was then incorporated into 5 diets at 0,15,20, 25 and 30\% levels for treatments $T_{1}, T_{2}, T_{3}, T_{4}$, and $T_{5}$, respectively as replacement for maize. The birds were maintained in deep litter system of five treatments withthree replicates each that were fed on layer mash. Wooden nests were provided for the birds to lay their eggs. Also feeders and drinkers were provided to serve feeds and water respectively. The parameters evaluated were feed intake, feed conversion ratio, percentage hen-day production (\%HDP), percentage daily egg production, age at first egg lay, egg laying period which is the length of laying period, percentage of egg laid per day per treatment, percentage hen house production(\%HHP) and age at peak of egg laying which were obtained in line with the reports of Oladunjoye et al. (2008) and Adeyemi et al. (2009). Eggs were collected four times daily between 0700 and 1600 hours to prevent breakages.

Carcass Analysis
At the end of the experiment, three layer chickens from each treatment (i.e. one from each replicate) were randomly selected and slaughtered. The live-weight, plucked weight, dressed weight, cut-up parts and organs were weighed and measured. The cut up parts were individually expressed as percentage of the plucked weight while organ weights were expressed as the percentage of the live weight.

\section{Chemical Analysis}

Homogenous samples of Prosopis africana seed coat meal, $\mathrm{T}_{1}, \mathrm{~T}_{2}, \mathrm{~T}_{3}, \mathrm{~T}_{4}$ and $\mathrm{T}_{5}$ diets were subjected to chemical analysis for proximate composition and gross energy determination in the Kappa Biotechnology Laboratory, Research Support R \& D and Analytical Service, Trans Amusement Park, Old Airport, Bodija GPO Box 12033, Ibadan, Oyo State, using the standard methods as indicated by A.O.A.C. (2000) and ballistic bomb calorimeter, respectively. Prosopis africana seed coat meals and feed samples were analyzed for crude protein using Kjeldahl technique; other proximate compositions that were analyzed for include ether extract, crude fiber and ash according to A.O.A.C. (2000) procedure. The nitrogen-free extract (NFE) was obtained by subtracting the $\%$ moisture, $\%$ crude protein $(\mathrm{CP}), \%$ crude fiber $(\mathrm{CF}), \%$ ether extract (EE) and \% ash from 100 and difference gave NFE (Aduku, 1993; Esonu, 2000). Metabolizable energy (ME) was calculated using the formula of Pauzenga (1985): (Metabolizable energy (ME) $(\mathrm{Kcal} / \mathrm{kg})=37 \times \% \mathrm{CP}+81.1 \times \% \mathrm{EE}+35.5 \times \% \mathrm{NFE}$.

\section{Statistical analysis}

The data obtained were subjected to one way analysis of variance (ANOVA) in a completely randomized design using the procedure outlined in the Minitab (2014). Where significant difference between treatment means occurred, they were separated using Minitab (2014) software.

\section{Results and discussion}

\section{The Performance Indices of Layer Chickens Fed Diets} Containing Prosopis africana Seed Coat Meal

The effect of dietary PASCM on the performance of laying pullets (Table 2) showed that as the PASCM inclusion levels increased and maize decreased in the diets, percentage hen day production (\%HDP) and other indices decreased except the FCR, age at first egg production and mortality. Age at first egg production increased with increased levels of maize substitution with PASCM but mortality for birds on PASCM diets $\left(T_{2}, T_{3}, T_{4}\right.$ and $\left.T_{5}\right)$ did not followed the same decreasing trend with increased in the level of PASCM. The decrease in the values of these parameters with increased level of PASCM inclusion in the diets implies that the PASCM may have reduced the efficient utilization of protein and energy of 
the diets due to its phytonutrients content. This result is in line with the result of Kamdoon (2015) had reported the impact of phytonutrients of PASCM which was responsible for decrease in feed intake, growth rate, feed efficiency, net metabolizable energy and protein digestibility in laying quails.

The values of \%HDP recorded in this study ranged from $34.48-64.90$ is lower than the range of values (64.97 68.47) reported by Okoeguale and Eruvbetine (2009) when unconventional feed supplemented with feed enzyme was fed to layer chickens. The differences in the values of \%HDP obtained in this study and the reported values may be due to differences in the strain of birds used. The feed intake in laying hens ( $\mathrm{g} / \mathrm{bird} /$ day) as recorded in this study averaged between $113.32-126.35$ which is higher than the values of 76.70 - 80.11 reported by Adeyemi et al. (2009) but comparable with the values $(120$ - 150) reported by Aduku (1993). Feed conversion ratio (feed/dozen egg) obtained ranged from $1.42-2.18$. Aduku (1993) reported value of 2.65. FCR in $0 \%$ ( control diets) showed most superiority over the PASCM based diets and efficiency of FCR decreased with increased levels of PASCM in the diet. This may be due to the PASCM contributory effect of higher fibre content asit replaced energy cereal grain (maize) (Aina, 1990) which necessitates the need for consumption of more feed to meet the energy requirement since birds eat to meet their energy needs (Lesson and Summers, 1997). More so, feed enzyme (polyzyme®) inclusion in PASCM based diets could not result in increased digestibility and therefore led to reduction in nutrient uptake. This finding is in support of the work of Okoeguale and Eruvbetine (2009) that supplemented feed enzyme with unconventional feed high in fibre recorded decrease in nutrient digestibility, reduction in nutrient uptake and poor performance.

The number of egg lay per hen $(104.19-177.49)$, dozen egg/hen (8.64 - 14.79), hen-housed production (\%) (37.48 64.90) and percentage egg production (34.73 - 58.40) showed decrease with increased levels of maize replacement by PASCM. This may be due to the fact that the birds became less efficient in utilizing the protein and energy content of the diets for productive functions due to inherent anti-nutritional factors in PASCM. Njoku and Obi (2009) and Sanni 2015) have reported the anti-nutritional factors in PASCM that affect performance in livestock and poultry. Age at first egg laying period (days) increased with increased levels of maize substituted with PASCM. The 0\% (control diet) PASCM inclusion level recorded egg production at the age of 133.00 days earlier than $T_{2}, T_{3}, T_{4}$ and $T_{5}(158.33$,
$155.69,168.67,174.33$ days, respectively). As the PASCM inclusion levels increased the age at first egg laying production increased. Egg laying period (day) however, decreased with increased levels of maize replaced by PASCM since the age at first egg production occurred earlier with less maize replaced by PASCM in the diets. This result supports the view of Njoku and Obi (2009) and Sanni (2015) who observed that anti-nutritional factors in PASCM reduce performance in livestock and poultry.

Feed cost per dozen eggs decreased with increased levels of maize substituted with PASCM. Treatment $\mathrm{T}_{1}(0 \%$ control diet) had the highest feed cost per dozen egg ( $\$ 265.72)$ while $\mathrm{T}_{5}$ (30\% PASCM) recorded the least cost ( 158.98). This is because the unit cost of PASCM was cheaper than the same unit cost of maize and more also less feed was consumed in PASCM based diets compared to 0\%(control diet). This result agrees with the report of Shamwol (2015) who observed that feed cost and cost of feed per gain decreased with increased levels of PASCM in the diets of laying Japanese quails. Hen-housed egg production (\%) and percentage egg produced decreased with increased inclusion levels of PASCM in the diets. This may be due to the PASCM contributory effect of higher fibre content and other anti-nutritional factors of the feed as it replaces energy cereal grains (Aina 1990) which necessitates the need for consumption of more feed to meet the energy requirement since birds eat to meet their energy needs (Lession and Summers, 1997). More so, enzyme inclusion in PASCM based diets $\left(T_{2}, T_{3}, T_{4}\right.$ and $\left.T_{5}\right)$ could not result in increased digestibility and therefore led to reduction in nutrient uptake. The egg yolk cholesterol mean values ranged from $226.66-$ $263.33 \mathrm{mg} / 100 \mathrm{~g}$. The egg yolk cholesterol values were significantly $(\mathrm{P}<0.05)$ affected by the dietary treatments. The values decreased linearly across the treatment groups. The highest and lowest values of cholesterol were observed in the groups fed $0 \%\left(\mathrm{~T}_{1}\right)$ and $30 \%\left(\mathrm{~T}_{5}\right)$ PASCM inclusion levels, respectively. The lowest level of egg yolk cholesterol observed in $30 \%\left(\mathrm{~T}_{5}\right)$ PASCM inclusion level could be attributed to high fibre content of PASCM based diets. This result is in line with the report of Idowu et al. (2000) who observed that dietary fibre binds with fat and its associates and therefore reduced their assimilation and further deposition in the tissues, organs and products. This result is also in agreement with the hypothesis that increased dietary fibre often result in reduction in the availability of cholesterol for incorporation into lipoprotein (Storey and Furumoto, 1990). This result also shows that there is an inverse 
relationship between the level of fibre in the diet and the cholesterol level of the egg yolk.

The non-significant $(\mathrm{P}>0.05)$ among the treatment means for the mortality observed in this study may imply that the feed was not the cost of the mortality. The diets may have been nutritionally adequate to sustain the hen's health and production despite the high level of crude fibre in the PASCM based diets. This result is in harmony with the finding of Fagbenro and Adebayo (2000) and Akinola and Ekine (2018) who observed that poor quality feed and poor environmental conditions cause high mortality, low productivity, feed condemnation and low rate of return on investment.

\section{Carcass Parameters of Layer Chickens}

Result of carcass yield of layer chickens fed on diets containing Prosopis africana seed coat meal is presented in Table 3 and showed that the live weight, pluck weight, dresses weight, visceral weight and dressing percentage that were not significantly $(\mathrm{P}>0.05)$ affected by the dietary treatments. The dressing percentage varied from $53.59 \%$ to $60.63 \%$ in the birds fed the experimental diets. The results obtained for dressing percentage in this study were similar across the dietary treatments. These results are in agreement with that of Torres et al. (2013) and Lakurbe et al. (2018) who reported that there were no significant different $(\mathrm{P}>$ 0.05 ) among the treatments in the whole carcass or weight of carcass parts of broiler chickens fed on sorghum based diets as energy source.

\section{Carcass Cut of Layer Chickens}

The evaluation of carcass cut of layer chickens in Table 4 showed that only the breast cut was significantly $(\mathrm{P}<0.05)$ affected by the dietary treatments. This result agrees with the report of Abu (2016) who showed that there were nosignificant different in meat yield and meat distribution among carcass cut or the proportional weight of the major visceral organs of broiler birds fed on Prosopis pod meal. The non - significance for most of the carcass cut determined in this study, according to Lakurbe et al. (2018) is an indication that the dietary treatments have no adverse effect on the parameters under investigation.

\section{Internal organs}

The result of the internal organs of layer chickens evaluated is presented in Table 5 and it showed that the liver, lung, heart, spleen, fat and caecum were not affected $(\mathrm{P}>0.05)$ by the dietary treatments however, the kidney, pancreas, Proventriculus, gizzard, empty gizzard, large intestine and small intestine were significantly $(\mathrm{P}<0.05)$ affected by the dietary treatments. The kidney which is an organ of detoxification, showed variation but was not significantly different from treatment 0\% (control diet) PASCM inclusion level. This is an indication that PASCM was not toxic enough to cause increase in the size of the kidney. Also some internal organs showed variation among treatment means, there was no consistent trend established. The variation among the treatments according to Yunusa et al. (2014) may not be due to different energy sources but probably due to varietal and individual differences among birds in feed consumption.

\section{Gastro-Intestinal Tract (GIT)}

The GIT length, small intestine, and large intestine that were expressed as the percentage of GIT length were affected (P < 0.05 )by the dietary treatments however caecum that was also expressed as the percentage of GIT length did not show significant different $(\mathrm{P}>0.05)$ among the dietary treatments. The indices of the GIT that showed variation did not follow any consistent trend. Therefore the variation may be due to individual differences in feed consumption rather than the effect of diets on the GIT indices. This result confirms with the result of Yunusa et al. (2014) who reported variation in characteristics including the GIT indices of avian species, fed different energy sources suggested that the difference may be due to varietal and individual differences.

\section{CONCLUSION}

The results of this study showed that most of the productive parameters were affected $(\mathrm{P}<0.05)$ by the dietary treatments. Mortality was not affected $(\mathrm{P}>0.05)$. Carcass yield, carcass cut and internal organs were not affected $(\mathrm{P}>$ $0.05)$ by the dietary treatments but GIT parts were affected (P $<0.05)$ by the diets. From the results obtained on the effect of PASCM on the layer performance and carcass characteristics $20 \%$ PASCM level of inclusion is recommended for optimal productivity since egg production constitutes the main index in layer chicken production. 
Table1: Ingredients and Dietary Composition of Pullet Layer Chicken Diets Experimental diets

\begin{tabular}{|c|c|c|c|c|c|}
\hline Ingredients & $0 \%$ & $15 \%$ & $20 \%$ & $25 \%$ & $30 \%$ \\
\hline Maize & 54.00 & 45.90 & 43.20 & 40.50 & 37.80 \\
\hline PASCM & - & 8.10 & 10.80 & 13.50 & 16.20 \\
\hline Sobean meal & 20.00 & 20.00 & 20.00 & 20.00 & 20.00 \\
\hline Rice bran & 14.00 & 14.00 & 14.00 & 14.00 & 14.00 \\
\hline Palm oil & 1.00 & 1.00 & 1.00 & 1.00 & 1.00 \\
\hline Blood meal & 2.00 & 2.00 & 2.00 & 2.00 & 2.00 \\
\hline Bone meal & 5.00 & 5.00 & 5.00 & 5.00 & 5.00 \\
\hline Limestone & 3.00 & 3.00 & 3.00 & 3.00 & 3.00 \\
\hline Vit./Min/permit & 0.25 & 0.25 & 0.25 & 0.25 & 0.25 \\
\hline Salt (Nacl) & 0.30 & 0.30 & 0.30 & 0.30 & 0.30 \\
\hline Lysine & 0.20 & 0.20 & 0.20 & 0.20 & 0.20 \\
\hline Methionine & 0.25 & 0.25 & 0.25 & 0.25 & 0.25 \\
\hline Enzymes & - & + & + & + & + \\
\hline Total & 100.00 & 100.00 & 100.00 & 100.00 & 100.00 \\
\hline \multicolumn{6}{|c|}{ Analyzed nutrients } \\
\hline Dry matter & 88.58 & 87.29 & 87.52 & 89.90 & 86.64 \\
\hline Crude protein & 16.33 & 16.64 & 16.92 & 17.06 & 16.40 \\
\hline Crude fibre & 4.48 & 5.59 & 5.12 & 5.47 & 5.48 \\
\hline Ether extract & 3.41 & 3.76 & 4.42 & 4.33 & 4.52 \\
\hline Ash & 12.19 & 11.38 & 11.13 & 11.74 & 11.86 \\
\hline \multicolumn{6}{|l|}{ Nitrogen-free } \\
\hline Extract (NFE) & 62.50 & 62.64 & 62.40 & 61.35 & 61.6 \\
\hline $\mathrm{ME}(\mathrm{kcal} / \mathrm{kg})^{*}$ & 3099.51 & 3144.34 & 3199.70 & 3160.31 & 3160.17 \\
\hline
\end{tabular}

ME:metabolizable energy

PASCM = Prosopis africana seed coat meal

* Vitamin/mineral premix supplied the following additional nutrients per $\mathrm{kg}$ of feed.

Table 2: Effect of Experimental Diet on Productive Parameters of Layer Chickens

\begin{tabular}{lllllll}
\hline & \multicolumn{5}{c}{ Experimental Diets } & \\
\cline { 2 - 5 } Parameter & $\mathrm{T}_{1}$ & $\mathrm{~T}_{2}$ & $\mathrm{~T}_{3}$ & $\mathrm{~T}_{4}$ & $\mathrm{~T}_{5}$ & SEM \\
\hline \% HDP & $64.90^{\mathrm{a}}$ & $53.27^{\mathrm{b}}$ & $50.02^{\mathrm{b}}$ & $47.72^{\mathrm{b}}$ & $37.47^{\mathrm{c}}$ & 2.10 \\
No of egg laid/hen & $177.49^{\mathrm{a}}$ & $145.44^{\mathrm{b}}$ & $136.55^{\mathrm{b}}$ & $130.00^{\mathrm{b}}$ & $104.18^{\mathrm{c}}$ & 0.00 \\
Dozen egg/hen & $14.79^{\mathrm{a}}$ & $12.12^{\mathrm{b}}$ & $11.38^{\mathrm{b}}$ & $10.84^{\mathrm{b}}$ & $8.68^{\mathrm{c}}$ & 0.70 \\
\% Mortality & 10.00 & 11.66 & 10.00 & 10.00 & 10.00 & 0.00 \\
\% egg production & $58.40^{\mathrm{a}}$ & $46.97^{\mathrm{b}}$ & $44.93^{\mathrm{bc}}$ & $42.88^{\mathrm{c}}$ & $34.93^{\mathrm{d}}$ & 0.00 \\
Average feed intake(g/bird/day) & 119.34 & 110.56 & 107.52 & 107.70 & 106.25 & 0.43 \\
FCR 1.8kg feed/dozen egg & $1.42^{\mathrm{a}}$ & $1.71^{\mathrm{a}}$ & $1.75^{\mathrm{a}}$ & $1.83^{\mathrm{b}}$ & $2.18^{\mathrm{b}}$ & 0.04 \\
\% hen day house production & $58.40^{\mathrm{a}}$ & $48.97^{\mathrm{b}}$ & $44.93^{\mathrm{bc}}$ & $42.88^{\mathrm{c}}$ & $34.93^{\mathrm{d}}$ & 0.06 \\
Feed cost/dozen egg(N) & $265.72^{\mathrm{a}}$ & $215.88^{\mathrm{b}}$ & $204.44^{\mathrm{bc}}$ & $195.14^{\mathrm{c}}$ & $158.94^{\mathrm{d}}$ & 0.20 \\
Date of first egg lay (days) & $133.00^{\mathrm{c}}$ & $158.33^{\mathrm{b}}$ & $155.66^{\mathrm{b}}$ & $168.66^{\mathrm{a}}$ & $174.33^{\mathrm{a}}$ & 0.50 \\
Egg laying period & $278.33^{\mathrm{a}}$ & $252.66^{\mathrm{b}}$ & $255.00^{\mathrm{b}}$ & $244.66^{\mathrm{bc}}$ & $237.00^{\mathrm{c}}$ & 0.09 \\
\hline
\end{tabular}




\begin{tabular}{|c|c|c|c|c|c|c|}
\hline Age at peak of laying & $240.00^{\mathrm{b}}$ & $251.33^{\mathrm{ab}}$ & $254.33^{\mathrm{ab}}$ & $264.66^{\mathrm{a}}$ & $259.66^{\mathrm{a}}$ & 0.04 \\
\hline Yolk cholesterol (mg/100g) & $263.33^{\mathrm{a}}$ & $256.66^{\mathrm{b}}$ & $250.64^{\mathrm{bc}}$ & $247.21^{\mathrm{c}}$ & $237.12^{c}$ & 0.01 \\
\hline
\end{tabular}

abcd means with different superscripts in the row are significantly different $(\mathrm{p}<0.05)$

$\% \mathrm{HDP}=$ percentage hen production

$\mathrm{AFI}=$ Average feed intake

Number (No.) of egg laid/hen

$\mathrm{FCR}=$ Feed conversion ratio

HHEP $=$ Hen-Housed egg production $(\%)$

Table 3: Effect of Prosopis africana on Carcass Parameters of Layer Chickens

\begin{tabular}{|c|c|c|c|c|c|c|}
\hline \multirow[t]{2}{*}{ Carcass yield } & \multicolumn{5}{|c|}{ Experimental Diets } & \multirow[b]{2}{*}{ SEM } \\
\hline & $\mathrm{T}_{1}$ & $\mathrm{~T}_{2}$ & $\mathrm{~T}_{3}$ & $\mathrm{~T}_{4}$ & $\mathrm{~T}_{5}$ & \\
\hline Live wt (g) & 1900.00 & 1933.30 & 1833.30 & 1733.30 & 1866.70 & 36.34 \\
\hline Pluck wt (g) & 1535.00 & 1571.30 & 1506.70 & 1489.30 & 1551.70 & 43.10 \\
\hline Dressed wt (g) & 1150.67 & 1125.33 & 1075.67 & 1051.33 & 998.33 & 30.10 \\
\hline Visceral wt (g) & 1205.00 & 1215.30 & 1161.00 & 1135.70 & 1076.30 & 30.85 \\
\hline Dressing $\%$ & 60.46 & 58.21 & 58.54 & 60.63 & 53.59 & 1.12 \\
\hline
\end{tabular}

$\mathrm{Wt}=$ weight

$\mathrm{SEM}=$ Standard error of mean

Table 4: Effect of Prosopis africana on Carcass Cut of Layer Chickens

\begin{tabular}{lllllll}
\hline Carcass cut (\% DW) & \multicolumn{7}{c}{ Experimental Diets } \\
\cline { 2 - 6 } & $\mathrm{T}_{1}$ & $\mathrm{~T}_{2}$ & $\mathrm{~T}_{3}$ & $\mathrm{~T}_{4}$ & $\mathrm{~T}_{5}$ & SEM \\
\hline Breast & $24.43^{\mathrm{b}}$ & $29.42^{\mathrm{a}}$ & $24.72^{\mathrm{b}}$ & $26.39^{\mathrm{ab}}$ & $25.51^{\mathrm{ab}}$ & 0.69 \\
Back & 16.12 & 16.86 & 16.00 & 16.41 & 16.69 & 0.20 \\
Thigh & 12.77 & 12.63 & 12.87 & 12.92 & 13.07 & 0.20 \\
Drum stick & 11.86 & 12.44 & 12.40 & 12.69 & 12.64 & 0.15 \\
Neck & 8.27 & 8.19 & 8.58 & 8.18 & 8.17 & 0.17 \\
Shank & 3.33 & 3.46 & 3.49 & 3.67 & 3.41 & 0.06 \\
Head & 4.18 & 4.45 & 4.55 & 4.29 & 4.35 & 0.11 \\
Wing & 12.21 & 11.81 & 11.43 & 11.24 & 10.95 & 0.24 \\
\hline
\end{tabular}

${ }^{\mathrm{a}, \mathrm{b}}$ Means with different superscript in the same row are significantly different $(\mathrm{P}<0.05)$

$\mathrm{SEM}=$ Standard error of mean

DW $=$ Dressed weight

Table 5: Effect of Prosopis africana on Internal Organs of Layer Chickens

\begin{tabular}{lllllll}
\hline Internal Organs (\% LW) & \multicolumn{5}{c}{ Experimental Diets } & SEM \\
\cline { 2 - 6 } & $\mathrm{T}_{1}$ & $\mathrm{~T}_{2}$ & $\mathrm{~T}_{3}$ & $\mathrm{~T}_{4}$ & $\mathrm{~T}_{5}$ & 0.15 \\
\hline Liver & 2.06 & 2.26 & 1.85 & 2.33 & 2.56 & 0.01 \\
Lungs & 0.51 & 0.43 & 0.50 & 0.52 & 0.47 & 0.02 \\
Heart & 0.72 & 0.59 & 0.61 & 0.60 & 0.57 & 0.03 \\
Kidney & $0.73^{\mathrm{a}}$ & $0.67^{\mathrm{ab}}$ & $0.75^{\mathrm{a}}$ & $0.78^{\mathrm{a}}$ & $0.52^{\mathrm{b}}$ & 0.01 \\
Spleen & 0.08 & 0.06 & 0.05 & 0.05 & 0.09 & $0.12^{\mathrm{b}}$ \\
Pancreas & $0.21^{\mathrm{ab}}$ & $0.17^{\mathrm{ab}}$ & $0.23^{\mathrm{a}}$ & $0.21^{\mathrm{ab}}$ & 0.01 \\
Proventriculus & $0.43^{\mathrm{ab}}$ & $0.44^{\mathrm{ab}}$ & $0.50^{\mathrm{a}}$ & $0.34^{\mathrm{b}}$ & $0.35^{\mathrm{b}}$ & 0.01 \\
Gizzard & $3.65^{\mathrm{ab}}$ & $3.89^{\mathrm{ab}}$ & $3.86^{\mathrm{ab}}$ & $4.26^{\mathrm{a}}$ & $3.30^{\mathrm{b}}$ & 0.12 \\
Empty gizzard & $2.24^{\mathrm{ab}}$ & $2.10^{\mathrm{b}}$ & $2.35^{\mathrm{ab}}$ & $2.67^{\mathrm{a}}$ & $1.94^{\mathrm{b}}$ & 0.08 \\
\hline
\end{tabular}




\begin{tabular}{lllllll}
\hline Fat & 1.47 & 0.68 & 0.45 & 0.68 & 0.75 & 0.20 \\
Large intestine $(\mathrm{g})$ & $0.76^{\mathrm{ab}}$ & $0.82^{\mathrm{ab}}$ & $0.91^{\mathrm{ab}}$ & $1.02^{\mathrm{a}}$ & $0.60^{\mathrm{b}}$ & 0.05 \\
Small intestine $(\mathrm{g})$ & $3.42^{\mathrm{ab}}$ & $4.51^{\mathrm{ab}}$ & $4.66^{\mathrm{a}}$ & $4.39^{\mathrm{ab}}$ & $2.96^{\mathrm{b}}$ & 0.25 \\
Caecum $(\mathrm{g})$ & 0.82 & 0.65 & 1.39 & 0.95 & 0.87 & 0.11 \\
\hline
\end{tabular}

$a, \bar{b}$ Means with different superscript in the same row are significantly different $(\mathrm{P}<0.05)$

SEM $=$ Standard error of mean

$\mathrm{LW}=$ Live weight

Table 6: Effect of Prosopis africana on GIT Parts of Layer Chickens

\begin{tabular}{lllllll}
\hline \multirow{2}{*}{ GIT parts } & \multicolumn{7}{c}{ Experimental Diets } & \\
\cline { 2 - 5 } & $\mathrm{T}_{1}$ & $\mathrm{~T}_{2}$ & $\mathrm{~T}_{3}$ & $\mathrm{~T}_{4}$ & $\mathrm{~T}_{5}$ & SEM \\
\hline GIT length (cm) & $203.67^{\mathrm{b}}$ & $228.67^{\mathrm{a}}$ & $249.00^{\mathrm{a}}$ & $242.33^{\mathrm{a}}$ & $201.67^{\mathrm{b}}$ & 5.94 \\
Small intestine (\%GIT) & $70.28^{\mathrm{b}}$ & $79.07^{\mathrm{a}}$ & $77.10^{\mathrm{a}}$ & $75.75^{\mathrm{ab}}$ & $76.78^{\mathrm{a}}$ & 0.19 \\
Large intestine (\% GIT) & $7.02^{\mathrm{a}}$ & $5.98^{\mathrm{ab}}$ & $5.48^{\mathrm{b}}$ & $6.59^{\mathrm{ab}}$ & $6.29^{\mathrm{ab}}$ & 1.03 \\
Caecum (\% GIT) & 19.50 & 17.19 & 16.68 & 16.65 & 18.65 & 0.63 \\
\hline
\end{tabular}

${ }_{a, b}$ Means with different superscript in the same row are significantly different $(\mathrm{P}<0.05)$

SEM $=$ Standard error of mean

GIT $=$ Gastro intestinal tract

$\mathrm{T}_{1}=$ Control diet

\section{REFERENCES}

[1] Abang, F.B.P, Ikwume T. and Ira-Ibor, B.O (2016). Cancass and Organ Characteristics of growing Japanese quail (coturnix coturnix japonics) fed diets containing boiled Prosopisafricana seed coat meal. Global Journal of Agriculture Research, 4(6); 1-6.

[2] Abu, D. O. 2016). Carcass and organ characteristics of broiler chickens fed Prosopis africana pod meal treated with rumen content. B. Agric., Department of Animal Production, College of Animal Science, Federal University of Agriculture, Makurdi, Benue State, Nigeria.

[3] Adeyemi, O. A., Agunbiade, J. A. and Oyefeso, A. O. (2009). Performance and early lay characteristics of growing pullets. In: Nigeria Poultry (Ola, S. I., Jegede, A. V. and Fafiolu, A. O., Eds.). Official Journal of the Worlds' poultryScience Association-Nigeria Branch, 6: 24 - 31.

[4] Aduku, A. O. (1993). Tropical feedstuff analysis Table. Department of Animal Science, Faculty of Agriculture, ABU, Samaru, Zaria, Nigeria.

[5] Aina, A. B. J. (1990). Replacing maize with cassava peels in finisher ration of cockerels. The effect on Cut off-pieces of the eviscerated cassava. Nigeria Journal of Animal Production, Vol. 17:17 - 22.

[6] Akinola, L. A. F. and Ekine, O. A. (2018). Evaluation of commercial layer feeds and their impact on performance and egg quality. Nigerian Journal of Animal Science, 20(2): 222 231.

[7] Aletor V.A (2005) Alternative energy and protein feed resources in livestock feeding. A Revisit of Possibilities and Annual Conference of Annual Science Association of Nigeria held at the University of Ado-Ekiti, Ekiti State $13^{\text {th }}$ September, 2005.

[8] AOAC (2000).Official Methods of Analysis. $17^{\text {th }}$ Edition.Association of Official Analytical Chemists. Washington, D.C.

[9] Bedford, M. R. and Morgan, A. J. (1996). The use of enzymes in poultry diets. World Poultry Science Journal, 52: 61 - 68.

[10] Chesson, A. (1993). Feed Enzyme. Animal Feed Science Technology, 45: 65-79.

[11] Classen, H.L. (1996). Cereal grain starch and exogenous enzymes in poultry diets. Animal Feed Science Technology, 62: $21-22$

[12] Dafwang, I.I and Shwarmen, E.B.N. (1996). Utilization of rice offal in practical rations for broiler chicks. Nigerian Journal of Animal Production, 23:21-23.

[13] Diarra, S.S., Kwari, I.O and Ubosi C.O. (2002). Potential of millet bran as substitute for wheat bran in broiler chicken diets. Journal of Sustainable Agricultural Environment, 4: $165-169$.

[14] Esonu, B. O. (2000). Animal Nutrition and Feeding:A Functional Apprroach. Rukzeal and Ruksons Associate Memorial Press, Oweri, Nigeria.

[15] Eruvbetine D., Tajudeem I.O ., Asdeosu, A.T. and Oloyede, A.A. (2003). Cassava (Manihot esculenta) leaf and tuber concentrate diets for broiler chickens. Bio-resources Technology, 86: 277 - 281.

[16] Fagbenro, O. A. and Adebayo, O. T. (2000). Areview of the animal and aquatic industries in Nigeria. FAO Corporate Document Repository.

[17] Idowu, O. M.O, Idowu, O. A., Oso, A. O., Fafiolu, A. O., Sule, R., Sorongbe, A. and Eruvbetine, D.(2006). 
Performance of laying hens fed cassava root wastes. Nigerian Poultry Science Journal, 4: 48-55. World's Poultry Science Association -Nigerian Branch.

[18] Kamdoon, I.B. (2015).The effect of feeding treated Prosopis africana seed coat meal on the haematological parameters of laying Japnese quails (Coturnix coturnix Japonics). B. Agric., Department of Ainmal Production, College of Animal Science, Federal University of Agriculture, Makurdi, Benue State, Nigeria.

[19] Kwari, I.D. (2008). Alternative energy feed resources in feeding poultry. Ph.D. Non-Thesis seminar. A paper presented at the Department of Animal Science, Faculty of Agriculture, University of Maiduguri, Maiduguri, Borno State, Nigeria.

[20] Lakurbe, O. A., Doma, U. D., Bello, K. M. and Abuber, M. (2018). Carcass characteristics and blood components of broiler chickens fed sorghum SK-5912 (Sorghum bicolor I. Moeneh) variety in mixture with different plant protein sources. Nigerian Journal of Animal Science, Vol. 20(2):250 $-257$.

[21] Lesson, S. and summers, J. D. (1997). Commercial Poultry Nutrition. $2^{\text {nd }}$ ed. University Books, University of Guelph, Guelph, ON, Canada; feeding programs for broilers. Pp. 207 254.

[22] Minitab (2014). Minitab statistical software manual. C. Version. Release 16, New York Media Cybernetics.

[23] Musa, R. R. and Olarinde, L. O. (2008). Cost and return implications in poultry farming in Ido Local Government Area of Oyo State. In: Animal Agriculture towards Millennium Development in Nigeria(Adeyemi, O. A., Ogungbean, R. M., Dada, R. O., Emolorunda, O. O., Awojibi, H. A., Ore, O. B. and Agunbiade, J. A. eds.). Proceeding of the 33rd Annual conference of the Nigerian Society for Animal production held at the College of Agricultural Science, OlabisiOnabanjo University, Ogun State, Nigeria, Pp. 312-315.

[24] Njoku, V. O. and Obi, C.(2009). Phytochemical constituents of some selected medical plants. Academic Journal of Pure and Applied Chemistry, 3(11):228-233.

[25] Odeh, M. O., Igwebuike, J. U., Ubosi, C. O. and Akwukwaegbu, S. E. (2012). Performance, digestibility and carcass characteristics of broiler chickens fed with graded levels of rice milling waste. Katsina-Ala Multidisciplinary Journal, 1 (2):38- 50.

[26] Oju (2003). Oju physical online, Oju LGA, Benue State SA3. Last edited on September 2015,at20:41,Time Zone WAT (CTC+1). Oju Physical Setting Online. Com 29 Jan.

[27] Okoeguale, A. W. and Eruvbetine, D. (2009). Performance and egg quality characteristics layers fed enzyme supplemented with unpeeled cassava root meal based diets. Poultry industry in West Africa. In: Towards Millennium Development Goals (Ola, S.I., Fafiolu, A. O. and Fatufe, A. A. Eds.). Book of Proceeding, $3^{\text {rd }}$ Nigerian International Poultry Summit. Pp. $114-118$.
[28] Oladunjoye, I. O., O Jebiyi, O. O. and Odunsi, A. A. (2008). Performance characteristics and egg quality of laying chickens fed lye treated cassava (Manihot esculenta Cranz) peel meal. Proceedings of the $13^{\text {th }}$ Annual Conference of the Animal Science Association of Nigeria (ASAN), $15^{\text {th }}-19^{\text {th }}$ September. ABU, Zaria, Kaduna State.

[29] Oluyemi, J. A. and Roberts, F. A. (2000). Poultry production in Warm wet climates, $2^{\text {nd }}$ Edition, spectrum Book Ltd, spectrum House Ring Road Ibadan, Nigeria, 176Pp.

[30] Pauzenga, U. (1985). Feeding parent stock. Zoo-tech. International, Pp. 22-25.

[31] Sanni, O.M. (2015). The effect of Iron tree (Prosopis africana) sees meal on the performance characteristics of laying Japanese quails (coturnic coturnix Japonica:. B. Agriculture, Department of Annual Production. Federal University of Agriculture, Makurdi, Benue State, Nigeria.

[32] Shamwol, E. L. (2015). Economic production of laying Japanese quails (Coturnix coturnix japonica) fed treated Prosopis africana seed coat meal. B. Agric., Department of Animal Production, College of Animal Science, Federal University of Agriculture, Makurdi, Benue State, Nigeria.

[33] Storey, J. A. and Furumoto, E. J. (1990). Dietary fibre and bile acid metabolism. Pages 364 - 365. In: dietary fibre Chemistry, Physiology and Health effects. Eds. Kritchevsky, D., Bonfield, C. and Anderson, J. W. Plenum Press; N. Y.

[34] Torres, A. A., Pizauro, J. M., Sores, Silvo, T. G. A. and Nogueira, W. C. L.(2013). Effects of corn replacement by sorghum in broiler chicks on performance and internal muscosa integrity. Poultry Sciences, 9: $1564-1571$.

[35] Yusuf, A.L. Tukur H.M., Abubakar, A. and Olarede, B. (2008). Energy requirement of layer chicks in a serni-and environment. Repositioning Animal Agriculture for the Realiszation of National Vision 2020. In: Proceeding of the $13^{\text {th }}$ Annual Conference of Animal Science Association of Nigeria (ASAN) (Bawa, G.S., Akpa, G.N., Jokthan, G.E., Kabir, M. and Abu, S.B., Eds.), September, Pp. 15 - 19.

[36] Yunusa, Y., Doma, U. D., Zahraddreen, D., Umar, A. and Abubar, S. B. (2014). Carcass and gut characteristics of broiler chickensfed different energy sources. International Journal of Poultry Sciences, 13(9): 525 - 529. 